\title{
Comparison of the solid phase and liquid-liquid extraction methods for methadone determination in human serum and whole blood samples using gas chromatography/mass spectrometry
}

\author{
Maja Veršić Bratinčević ${ }^{1}$, Tanja Visković ${ }^{2}$, and Davorka Sutlović ${ }^{1}$ \\ Department of Forensic Medicine, University of Split School of Medicine ${ }^{1}$, Department of Pathology and Forensic \\ Medicine, University Hospital Centre Split ${ }^{2}$, Split, Croatia
}

[Received in February 2017; Similarity Check in February 2017; Accepted in December 2017]

The aim of this study was to determine the optimal biological sample and the optimal extraction technique for monitoring methadone concentrations in biological samples. We analysed methadone in serum and whole blood samples using gas chromatography/mass spectrometry (GC/MS). Before analysis, we compared five solid-phase extraction (SPE) and two liquid-liquid extraction (LLE) methods and determined that SPE with Supelco LC-18 in serum yielded the best extraction efficiency. The limit of detection was $10 \mathrm{ng} \mathrm{mL}^{-1}$ and the limit of quantification $25 \mathrm{ng} \mathrm{mL}^{-1}$. Correlation coefficient was over 0.999 for the methadone calibration curve in linear range from 50 to $2000 \mathrm{ng} \mathrm{mL}^{-1}$. Intra and inter-day accuracy and precision of the method was satisfactory. The method was successfully applied for determining serum methadone in patients on maintenance therapy.

KEY WORDS: biological samples, extraction techniques, GC/MS; substitution therapy

Methadone is used to treat the opioid withdrawal syndrome and relieve pain $(1,2)$. When taken by mouth, its bioavailability is as high as $90 \%$, and its absorption by the gastrointestinal tract so fast that it can be detected in blood within 30 minutes of administration.

Like any other drug, methadone may have short and long-term adverse effects, such as nausea, itch, pupil contraction, and difficulty breathing (3). These side effects can be alleviated by proper dosing. Dose adjustments, such as those in methadone maintenance therapy, depend on accurate information about methadone levels in biological samples.

However, determining it in biological samples, usually whole blood, serum, or plasma, can be quite challenging due to a number of interferences that may blur the findings and their interpretation. These samples usually require purification before analysis. They are purified by extraction techniques that remove unwanted components and concentrate the compound of interest (4).

There are several analytical techniques for the determination of methadone and methadone metabolites in biological samples. The most frequent and most reliable are gas chromatography $(5,6)$ and liquid chromatography $(3,7,8)$.

Correspondence to: Maja Veršić Bratinčević, University of Split School of Medicine, Department of Forensic Medicine, Šoltanska 2, 21000 Split, Croatia.E-mail:mversic@gmail.com
Biological samples are usually prepared for instrumental analysis with solid-phase extraction (SPE) $(7,9,10)$ or liquid-liquid extraction (LLE) (11-13).

The aim of this study was to see which of the LLE and SPE methods is optimal for determining whole blood and serum methadone with gas chromatography/mass spectrometry (GC/MS). Using the optimal method we also compared whole blood and serum to see which better fits routine laboratory application.

\section{MATERIALS AND METHODS}

\section{Solvents and reagents}

All solvents used for extraction were of analytical grade. Methadone standard solution ( $1 \mathrm{mg} \mathrm{mL}^{-1}$ of methanol) was purchased from Lipomed AG (Arlesheim, Switzerland). Methanol, ethyl acetate, chloroform, dichloromethane, concentrated hydrochloric acid, sodium diphosphate dihydrate, sodium phosphate dihydrate, sodium hydroxide, sodium sulphate anhydrous, L-cysteine, and isopropanol were purchased from Merck (Darmstadt, Germany) and double-distilled water from Becton Dickinson (Franklin Lakes, NJ, USA). Urine toxicology control DAU HC2 was purchased from UTAK Laboratories (Valencia, CA, USA) and contained 26 drug analytes (amphetamines, barbiturates, benzodiazepines, cannabinoids, cocaine, opiates, 
phencyclidine, propoxyphene and tricyclic antidepressants drug class). Bond Elut NEXUS SPE columns were bought from Agilent Technologies (Santa Clara, CA, USA), and Supelclean Envi Florisil, Supelclean LC-18, ReversedPhase, and Amberlite XAD-2 Polymeric Adsorbent from Supelco, Sigma Aldrich (St. Louis, MO, USA).

Phosphate buffer was prepared in a volumetric flask of $500 \mathrm{~mL}$ by dissolving sodium phosphate dihydrate phosphate $(1.56 \mathrm{~g})$ and sodium dihydrogen phosphate dihydrate $(1.77 \mathrm{~g})$. The solutions were combined and adjusted to $\mathrm{pH} 6.9$ using $4 \mathrm{~mol} \mathrm{~L}^{-1}$ sodium hydroxide solution. The obtained buffer solution was filtered through vacuum filter with the pore size of $0.2 \mu \mathrm{m}$.

The ratio between dichloromethane and isopropanol used in SPE for elution was 9:1 (v/v 9:1).

\section{Standard solution}

Methadone working standard solutions were prepared by dilution with methanol to a final concentration of $10 \mu \mathrm{g} \mathrm{mL}^{-1}$ and were used to prepare calibration samples. To establish linearity, a calibration curve was calculated by analysing drug-free blood samples spiked with methadone at the concentrations of 50,100, 500, 1000, and $2000 \mathrm{ng} \mathrm{mL}^{-1}$.

\section{Samples and sample preparation}

Human blood samples were obtained from healthy volunteers and tested with GC/MS. All samples were negative to methadone. Blood was stored in containers that did not contain an anticoagulant. The concentration of methadone in all the prepared whole blood and serum samples was $5000 \mathrm{ng} \mathrm{mL}^{-1}$. All total ion chromatograms (areas under the curve, AUC) were compared for each sample type separately. The extraction method that made the greatest response to the instrument was determined and validated, and that method was further used for laboratory testing of methadone concentration. Serum was separated by centrifugation (at $1500 \mathrm{~g}$ for $15 \mathrm{~min}$ ) at room temperature after the formation of coagulum (15-30 $\mathrm{min}$ ) and stored in a refrigerator at $+4{ }^{\circ} \mathrm{C}$ for a maximum of 3 days. Unlike serum, whole blood samples were analysed immediately to avoid coagulation.

Proteins in serum samples ( $1 \mathrm{~mL}$ aliquots) for SPE were precipitated with acetonitrile and isopropanol and applied to preconditioned SPE cartridges.

We also used the best extraction method to analyse 10 serum samples from patients undergoing methadone treatment. These clinical samples were taken as part of standard toxicological analysis for legal and illegal drugs.

The study was approved by the Ethics Committee of the University Hospital Split (approval ref. No. 530-01/1201/164).

\section{Solid-phase extraction (methods 1-5)}

Whole blood samples $(950 \mu \mathrm{L})$ were mixed with a $50 \mu \mathrm{L}$ standard solution and prepared by adding $4 \mathrm{~mL}$ of phosphate buffer (pH 6.9) drop by drop at constant twirling. After a three-minute pause, the samples were centrifuged at $1500 \mathrm{~g}$ for $10 \mathrm{~min}$ and $4 \mathrm{~mL}$ of supernatant separated from the rest.

One-millilitre serum samples were precipitated with $2 \mathrm{~mL}$ of acetonitrile-isopropanol mixture (v/v 1:1).

The procedure for SPE sample preparation (using the standard solution of methadone and buffering of samples) was the same as described above (Figure 1).

We developed five SPE methods to determine methadone in whole blood and serum samples (see methods 1-5 below). The columns used for SPE are common in the preparation of biological samples for toxicological analysis. All the SPE columns were conditioned with $2 \mathrm{~mL}$ of phosphate buffer and $1 \mathrm{~mL}$ of sterile water prior to sample

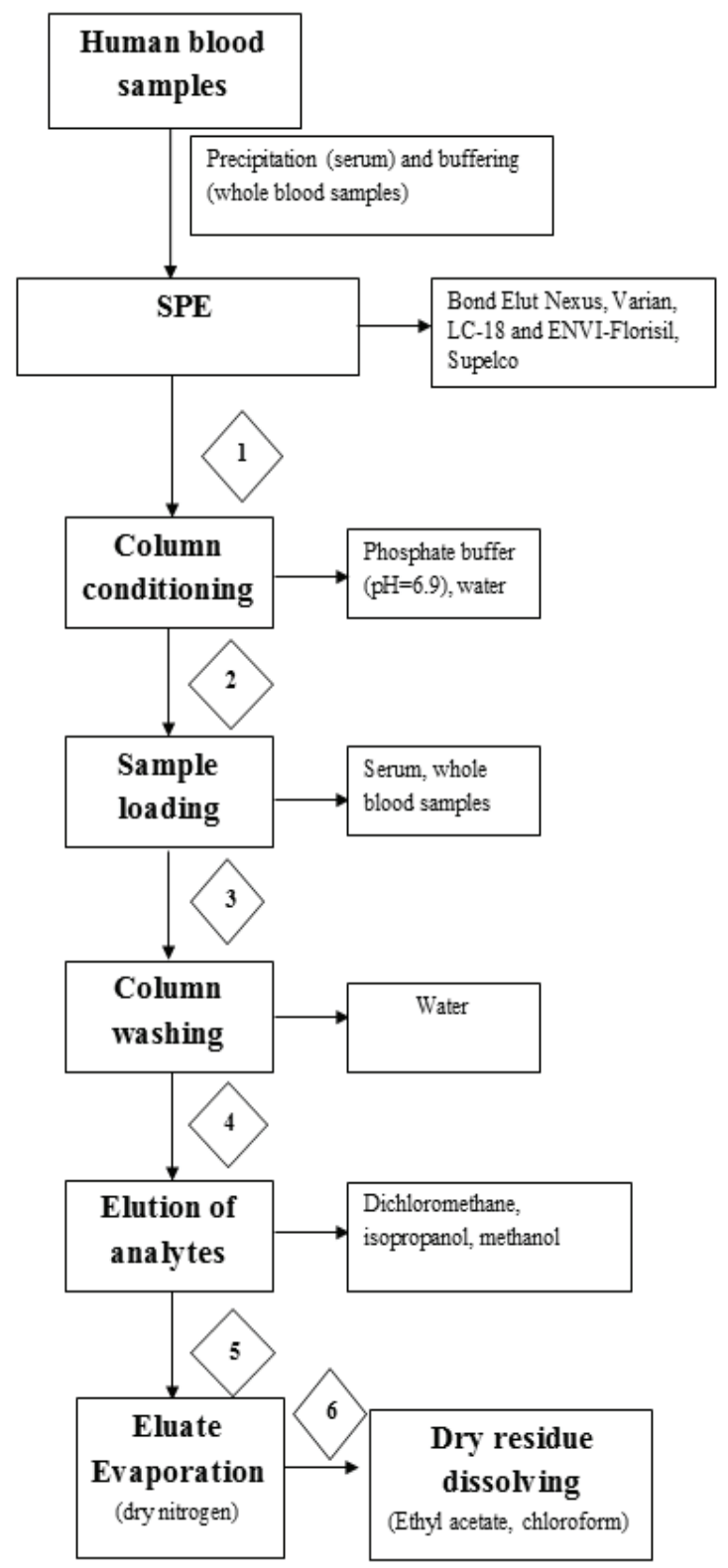

Figure 1 Flowchart for testing the whole blood and serum samples spiked with standard solutions of methadone in order to select optimal SPE extraction method for quantitative determination of methadone with GC/MS 
loading. The samples were passed through columns using low vacuum $\left(1 \mathrm{~mL} \mathrm{~min}{ }^{-1}\right)$, and the columns were washed with $1 \mathrm{~mL}$ of distilled water for methods $1-4$. The eluates were evaporated under a nitrogen stream. For methods 1 and 2, we tested Bond Elut Nexus SPE columns using a different elution solvent, while for methods 3 and 4 we used the same elution solvent, but the dry residue was redissolved with different organic solvents.

Method 1: Samples were eluted from the Bond Elut Nexus SPE column with $2 \times 6 \mathrm{~mL}$ of dichloromethaneisopropanol mixture (v/v 9:1) in a glass tube. The eluates were evaporated under a nitrogen stream and the obtained extracts dissolved in $30 \mu \mathrm{L}$ of ethyl acetate and transferred to glass tubes for GC/MS analysis.

Method 2: Samples were eluted from the Bond Elut Nexus SPE column with $2 \mathrm{~mL}$ of methanol, and the eluates collected in glass test tubes and evaporated under a stream of nitrogen. The extracts were dissolved in $30 \mu \mathrm{L}$ of ethyl acetate and transferred to glass tubes for GC/MS analysis.

Method 3: Samples were eluted from the Supelco LC18 SPE cartridge with $2 \mathrm{~mL}$ of methanol in a glass chemical tube. After evaporation under a stream of nitrogen, a dry residue was dissolved in $30 \mu \mathrm{L}$ of chloroform, and the extracts transferred to glass tubes for GC/MS analysis.

Method 4: Samples were eluted from the Supelco ENVI Florisil SPE column with $2 \mathrm{~mL}$ of methanol, and the eluates collected in glass test tubes and evaporated under a stream of inert nitrogen. The extracts were dissolved in $30 \mu \mathrm{L}$ of ethyl acetate and transferred to glass tubes for GC/MS analysis.

Method 5: Amberlite $\mathrm{XAD}_{2}$ resin adsorbent in a champagne column was conditioned with distilled water and methanol (25 $\mathrm{mL}$ each). The supernatant was passed through the column. The column was washed with distilled water $(25 \mathrm{~mL})$. Samples were then eluted through anhydrous sodium sulphate with a mixture of ethyl acetate and chloroform ( $\mathrm{v} / \mathrm{v} 3: 2)$. The resulting eluates were evaporated in a fume hood. The extracts were dissolved in $30 \mu \mathrm{L}$ of ethyl acetate and transferred to glass vial inserts for $\mathrm{GC} /$ MS analysis.

\section{Liquid-liquid extraction (methods 6 \& 7)}

For this study we tested two liquid-liquid extractions, which differed only in the preparation of the tubes before adding whole blood and serum samples (Figure 2).

After the samples were put in the tube, we followed the same procedure for both, as follows.

Method 6 was developed in the house. To a glass tube with screw and a cap we added $1.8 \mathrm{~g}$ of sodium tungstatedihydrate and $2 \mathrm{~mL}$ of ethyl acetate-dichloromethane mixture (v/v 1:3).

For method 7 we used Varian's Toxi-Tubes A(Palo Alto, CA, USA).

For both LLE methods, to $1 \mathrm{~mL}$ of whole blood or serum we added $4 \mathrm{~mL}$ of phosphate buffer ( $\mathrm{pH}$ 6.9) drop by drop.

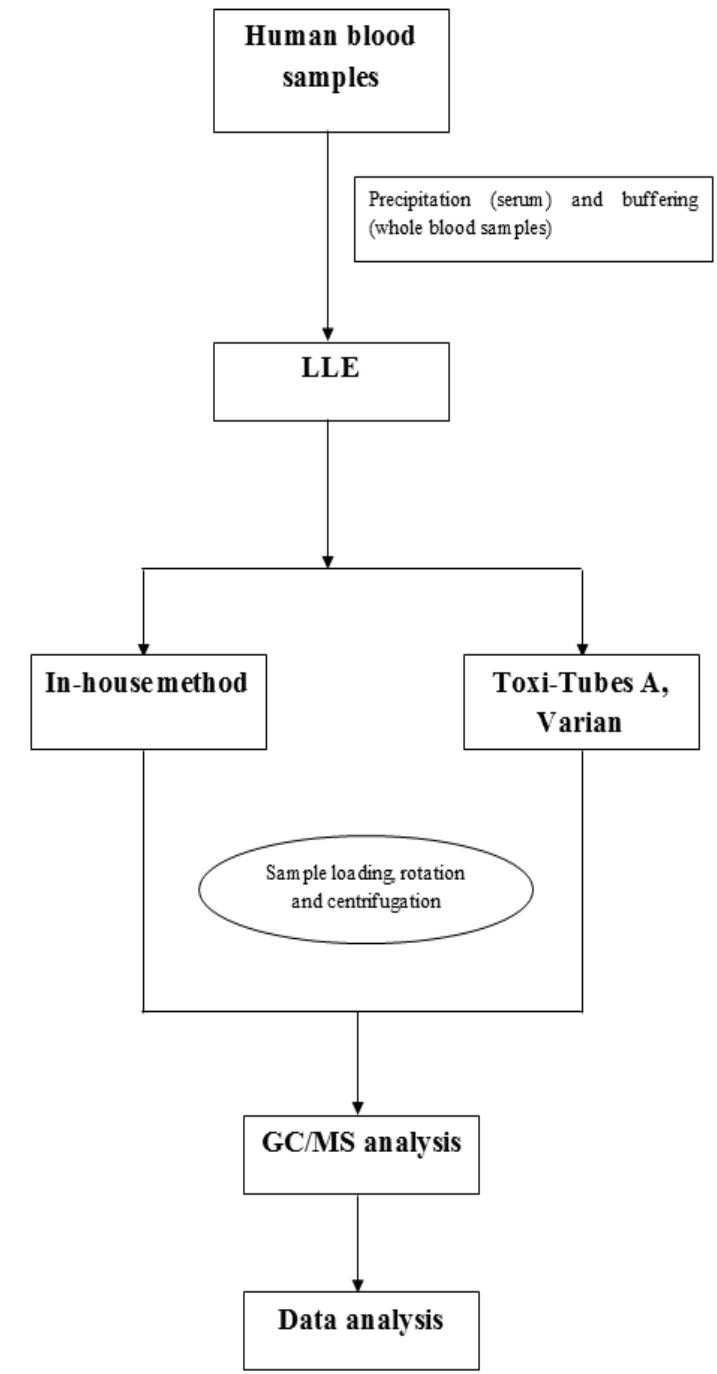

Figure 2 Flowchart for testing the whole blood and serum samples spiked with standard solutions of methadone in order to select the optimal LLE extraction method for quantitative determination of methadone with GC/MS

The serum samples were then precipitated with a $2 \mathrm{~mL}$ mixture of acetonitrile and isopropanol (v/v 1:1), pipetted into tubes for both methods 6 and 7, and gently mixed for $2 \mathrm{~min}$. After a 3 minute pause, the tubes with $4 \mathrm{~mL}$ of serum or whole blood supernatant were capped and mixed in a rotary mixer at $0.56 \mathrm{~g}$ for $10 \mathrm{~min}$, and then centrifuged at $1500 \mathrm{~g}$ for another $10 \mathrm{~min}$. The eluate was evaporated to dryness in a fume hood. The extracts were dissolved in $30 \mu \mathrm{L}$ of chloroform and transferred to glass tubes for $\mathrm{GC} /$ MS analysis.

\section{Chromatography}

For both extraction methods we followed the same GC/ MS procedure on a Shimadzu GC/MS QP 2010 (Kyoto, Japan). The chromatographic column was RTX-5MS (5\% diphenyl-95\% dimethyl polysiloxane, length $30 \mathrm{~m}$, diameter $0.25 \mathrm{~mm}$, film thickness $0.25 \mu \mathrm{m}$, Restek, Bellefonte, PA, USA). The analyses were performed using MS full scan (40-600 m/z). One $\mu \mathrm{L}$ of sample was injected 
in splitless mode. The injector port temperature was set to $250^{\circ} \mathrm{C}$. Ultra-pure grade helium was used as the carrier gas at a flow rate of about $1.5 \mathrm{~mL} \mathrm{~min}{ }^{-1}$. The initial column temperature of $90^{\circ} \mathrm{C}$ was held for $3 \mathrm{~min}$, then programmed to rise to $270{ }^{\circ} \mathrm{C}$ at $20^{\circ} \mathrm{C} \mathrm{min}-1$, and held for $3 \mathrm{~min}$.

\section{Extraction method validation}

Validation included the linearity, sensitivity, selectivity, intra- and inter-day precision, and accuracy of the methods tested on human serum samples.

The calibration curve was obtained by analysing five serum solutions spiked with methadone in the concentration range of 50-2000 $\mathrm{ng} \mathrm{mL}^{-1}$. For each standard solution we made three replicate measurements.

Selectivity was evaluated by injecting six samples of blank serum matrices to exclude potential interferences.

Accuracy and precision were evaluated based on three replicates of six serum samples spiked with methadone in the concentrations of 100, 500, and $1000 \mathrm{ng} \mathrm{mL}^{-1}$. Accuracy (bias) is expressed as the percentage of the true value, and precision as the relative standard deviation.

Reproducibility was established using the same range of concentrations as described above. Each concentration was measured in triplicate over five consecutive days. For each value we statistically determined its relative standard deviation using the Graph Pad Prism Software (San Diego,
CA, USA) and MS Office Excel 2010 packages (Microsoft, Redmond, WA, USA).

Selectivity was tested by analysing serum samples spiked with a mixture of most common licit and illicit drugs (DAU HC2).

\section{RESULTS AND DISCUSSION}

\section{Comparison of extraction methods and biological samples}

The comparison of the seven extraction methods for whole blood samples showed that method 3 - extraction with Supelco LC-18 columns - yielded the best result (Figure 3).

The same extraction method also yielded the best results for serum samples (Figure 4), and the two sample types did not differ significantly, in fact, the detector responses were almost identical, which suggests that both whole blood and serum can be used for toxicology screening for methadone (Figure 5).

\section{SPE method 3 validation findings}

The linearity of the methadone measurements was confirmed with the concentration ranges from 50 to

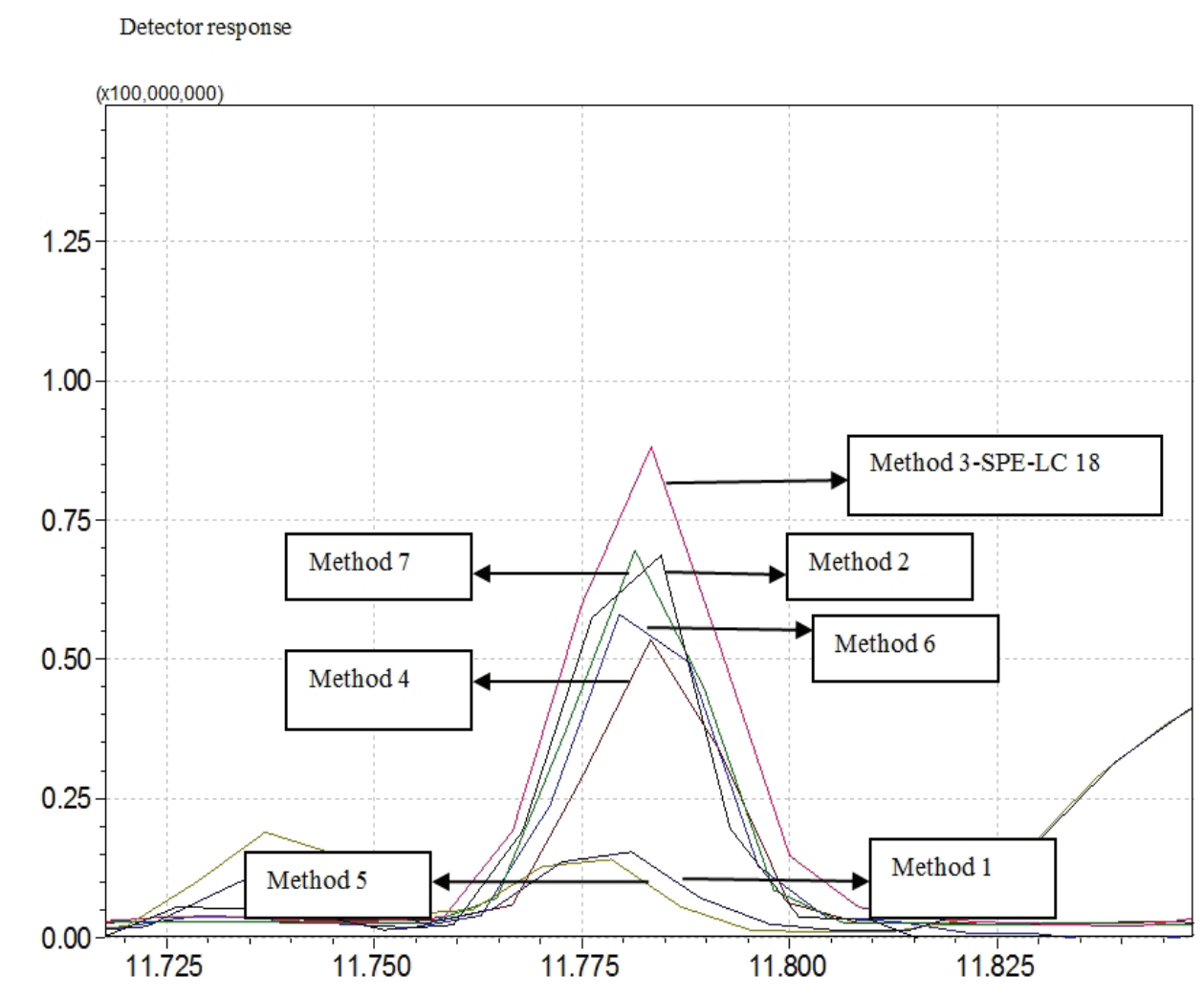

Time $(\min )$

Figure 3 Total ion chromatograms of whole blood samples spiked with a $5 \mu \mathrm{g} \mathrm{LL}^{-1}$ methadone solution. Comparison of the results obtained from the whole blood samples using all seven extraction methods 
$2000 \mathrm{ng} \mathrm{mL}^{-1}$ with the obtained correlation coefficient was more than 0.999 .

The method was also highly selective, as the peaks of the tested licit and illicit drug components in serum did not overlap.

The limit of methadone quantification was $25 \mathrm{ng} \mathrm{mL}^{-1}$, and the limit of detection $10 \mathrm{ng} \mathrm{mL}^{-1}$ (signal-to-noise ratio $\geq 3$ ).

Tables 1 and 2 show the intra- and inter-day accuracy and precision of method 3 , respectively.

Among the other methods, Bond Elut column Nexus also gave good detector response for methadone, and can be used for SPE. Liquid-liquid extraction with Toxi-Tube A showed good results in the extraction of whole blood samples, and its use is very suitable for easy, fast, and costeffective sample preparation in the laboratory. The lowest results were for the extraction in the champagne column packed with Amberlite XAD2 resin, and this extraction procedure is not recommended for methadone determination and quantification in either whole blood or serum.

The choice of the extraction method should also depend on the practical issues, such as matrix selection. One of the advantages of serum over whole blood samples is that they do not require an additional preparation step for extraction. However, in terms of GC/MS measurement, both whole blood and serum yield nearly identical results with the method we validated. This implies that both biological samples can be successfully applied in clinical and forensic toxicology.

\section{CONCLUSION}

Our study suggests that SPE has an edge over LLE for both serum and whole blood samples. The validated extraction method 3 with Supelco LC-18, which achieved the best results, is simple and reliable and can easily be implemented in everyday laboratory practice for the determination of methadone in serum or whole blood.
However, serum samples do not require the precipitation step in preparation, which makes them more suitable and stable for GC/MS analysis. The method showed satisfactory precision and accuracy. The measured RSD value was below $10 \%$. The method can be of great importance when it is necessary to determine the level of methadone in order to tailor therapy for each patient undergoing maintenance programmes.

\section{REFERENCES}

1. El-Beqqali A, Abdel-Rehim M. Quantitative analysis of methadone in human urine samples by microextraction in packed syringe-gas chromatography-mass spectrometry (MEPS-GC-MS). J Separ Sci 2007;30:2501-5. doi: 10.1002/ jssc. 200700067

2. Kharasch ED. Current concepts in methadone metabolism and transport. Clin Pharmacol Drug Dev 2017;6:125-34. doi: $10.1002 /$ cpdd. 326

3. Samanidou VF, Anastasiadou K, Papadoyannis IN. Development and validation of a rapid HPLC method for the determination of methadone and its main metabolite EDDP in biological fluids, following SPE. J Liq Chromatogr Relat Technol 2006;29:889-902. doi: 10.1080/10826070500531433

4. Juhascik MP, Jenkins AJ. Comparison of liquid/liquid and solid-phase extraction for alkaline drugs. J Chromatogr Sci 2009;47:553-7. PMID: 19772726

5. Diong SH, Mohd Yusoff NS, Sim MS, Raja Aziddin RE, Chik Z, Rajan P, Abdul Rashid R, Chemi N, Mohamed Z. Quantitation of methadone and metabolite in patients under maintenance treatment. J Anal Toxicol 2014;38:660-6. doi: 10.1093/jat/bku096

6. Hsu Y-C, Chen B-G, Yang S-C, Wang Y-S, Huang S-P, Huang M-H, Chen TJ, Liu HC, Lin DL, Liu RH, Jones AW. Methadone concentrations in blood, plasma, and oral fluid determined by isotope-dilution gas chromatography-mass spectrometry. Anal Bioanal Chem 2013;405:3921-8. doi: 10.1007/s00216-012-6460-2

7. Rudaz S, Veuthey JL. Stereoselective determination of methadone in serum by HPLC following solid-phase

Table 1 Method 3 intra-day accuracy and precision

\begin{tabular}{|c|c|c|c|}
\hline $\begin{array}{l}\text { Methadone concentration } \\
\left(\mathrm{ng} \mathrm{mL}^{-1}\right)\end{array}$ & $\begin{array}{l}\text { Measured methadone } \\
\text { concentration } \\
(\mathrm{ng} \mathrm{mL}-1)\end{array}$ & $\begin{array}{c}\text { Accuracy } \\
\text { (\% bias) }\end{array}$ & $\begin{array}{c}\text { Precision } \\
(\% \mathrm{CV})\end{array}$ \\
\hline 100 & $100.22 \pm 1.84$ & 0.22 & 0.75 \\
\hline 500 & $501.39 \pm 1.75$ & 0.28 & 0.71 \\
\hline 1000 & $1006 \pm 11.08$ & 0.64 & 4.52 \\
\hline
\end{tabular}

Mean $\pm S D ; n=6 ; C V=$ standard deviation/mean $\times 100$; each concentration was measured in triplicate over five consecutive days

Table 2 Method 3 inter-day accuracy and precision of quality control samples for methadone

\begin{tabular}{|c|c|c|c|}
\hline 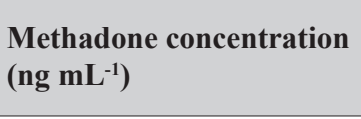 & 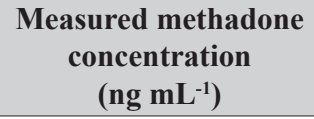 & $\begin{array}{l}\text { Accuracy } \\
\text { (\% bias) }\end{array}$ & $\begin{array}{l}\text { Precision } \\
(\% \mathrm{CV})\end{array}$ \\
\hline 100 & $101.51 \pm 3.67$ & 1.48 & 0.94 \\
\hline 500 & $506.67 \pm 11.63$ & 1.32 & 3.01 \\
\hline 1000 & $1004.99 \pm 22.17$ & 0.5 & 5.73 \\
\hline
\end{tabular}

Mean $\pm S D ; n=15 ; C V=$ standard deviation/mean $\times 100$; each concentration was measured in triplicate over five consecutive days 


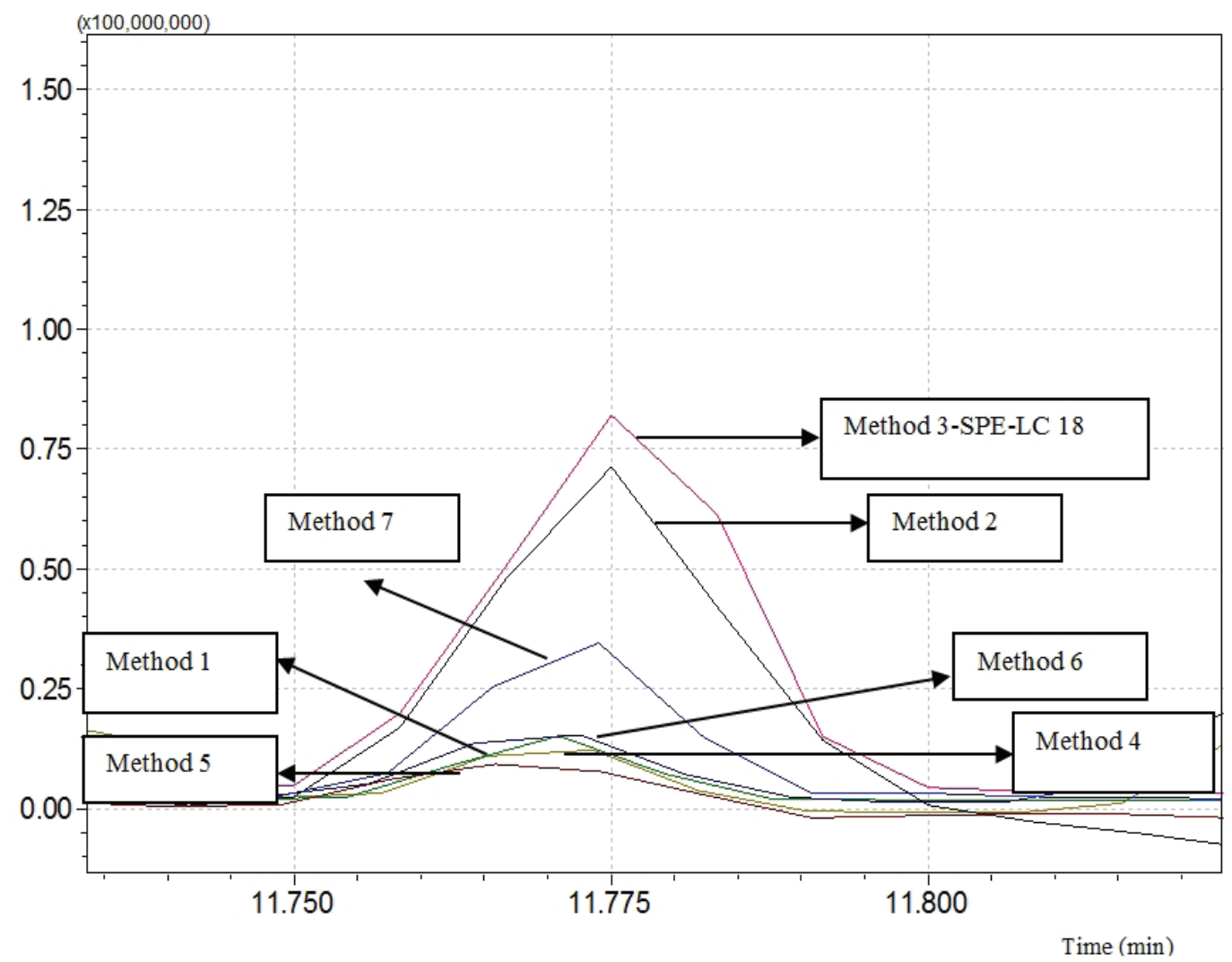

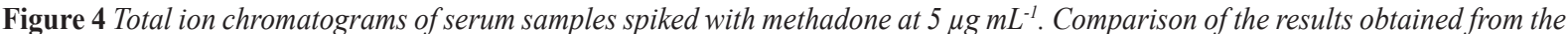
serum samples using all seven extraction methods

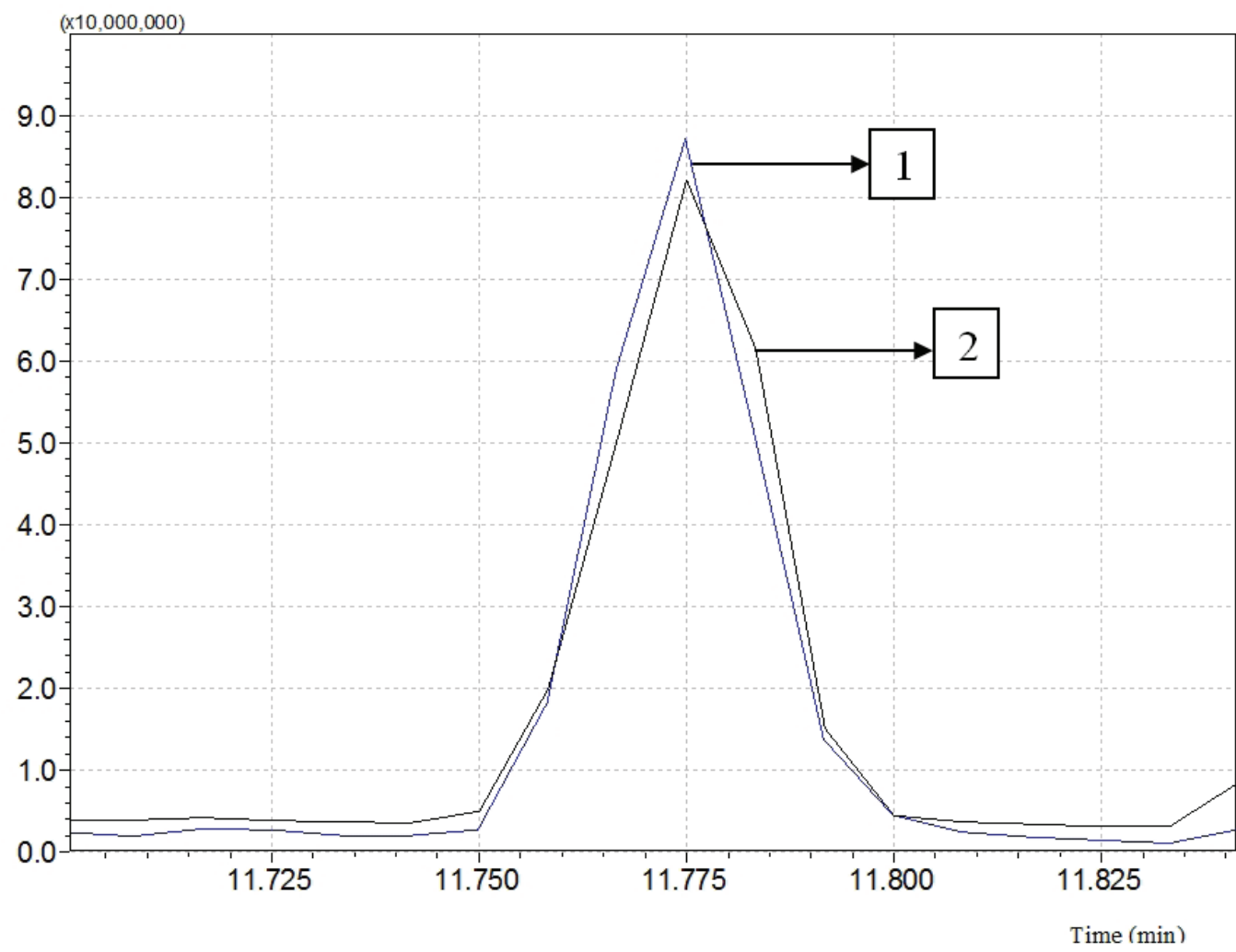

Figure 5 Comparison of total ion chromatograms for serum [1] and whole blood samples [2] spiked with methadone $\left(5 \mu g \mathrm{~mL}^{-1}\right)$ and obtained with extraction method 3 (SPE LC-18) 
extraction on disk. J Pharm Biomed Anal 1996;14:1271-9. PMID: 8818045

8. Nakhla DS, Hussein LA, Magdy N, Abdallah IA, Hassan HE. Precise simultaneous quantification of methadone and cocaine in rat serum and brain tissue samples following their successive i.p. administration. J Chromatogr B Analyt Technol Biomed Life Sci 2017;1048:19-29. doi: 10.1016/j. jchromb.2017.01.048

9. Cheng YF, Neue UD, Woods LL. Novel high-performance liquid chromatographic and solid-phase extraction methods for quantitating methadone and its metabolite in spiked human urine. J Chromatogr B Biomed Sci Appl 1999;729:1931. doi: 10.1016/S0378-4347(99)00116-4

10. He H, Sun C, Wang XR, Pham-Huy C, Chikhi-Chorfi N, Galons H, Thevenin M, Claude JR, Warnet JM. Solid-phase extraction of methadone enantiomers and benzodiazepines in biological fluids by two polymeric cartridges for liquid chromatographic analysis. J Chromatogr B Anal Technol
Biomed Life Sci 2005;814:385-91. doi: 10.1016/j.jchromb. 2004.10.048

11. Frost M, Kohler H, Blaschke G. Enantioselective determination of methadone and its main metabolite 2-ethylidene-1,5-dimethyl-3,3-diphenylpyrrolidine (EDDP) in serum, urine and hair by capillary electrophoresis. Electrophoresis 1997;18:1026-34. doi: 10.1002/elps.1150 180627

12. Schmidt N, Brune K, Geisslinger G. Stereoselective determination of the enantiomers of methadone in plasma using high-performance liquid chromatography. J Chromatogr B Biomed Sci Appl 1992;583:195-200. doi: 10.1016/03784347(92)80552-2

13. Norris RL, Ravenscroft PJ, Pond SM. Sensitive highperformance liquid chromatographic assay with ultraviolet detection of methadone enantiomers in plasma. J Chromatogr B, Biomed Sci Appl 1994;661:346-50. doi: 10.1016/03784347(94)00341-6

\section{Usporedba ekstrakcija čvrstom i tekućinsko-tekućinskom fazom za određivanje metadona u uzorcima seruma i pune krvi plinskom kromatografijom - masenom spektrometrijom}

Cilj ovog istraživanja bio je utvrditi optimalni biološki uzorak i optimalnu tehniku ekstrakcije za praćenje koncentracija metadona u biološkim uzorcima. Analizirali smo metadon u uzorcima seruma i pune krvi plinskom kromatografijom masenom spektrometrijom (GC/MS). Prije analize uspoređivali smo postupak ekstrakcije čvrstom fazom (engl. solid phase extraction, SPE) i metode ekstrakcije tekućinsko-tekućinske (engl. liquid-liquid extraction, LLE) i utvrdili da SPE sa Supelco LC-18 u serumu daje najbolju učinkovitost ekstrakcije. Granica detekcije bila je $10 \mathrm{ng} \mathrm{mL}^{-1}$, a granica kvantifikacije $25 \mathrm{ng} \mathrm{mL}^{-1}$. Koeficijent korelacije bio je veći od 0,999 za kalibracijsku krivulju u linearnom rasponu od 50 do $2000 \mathrm{ng} \mathrm{mL} \mathrm{m}^{-1}$. Metoda je pokazala zadovoljavajuću točnost i preciznost te je uspješno primijenjena za određivanje metadona u uzorcima seruma pacijenata na terapiji odvikavanja. 